\title{
Under the Black Umbrella
}





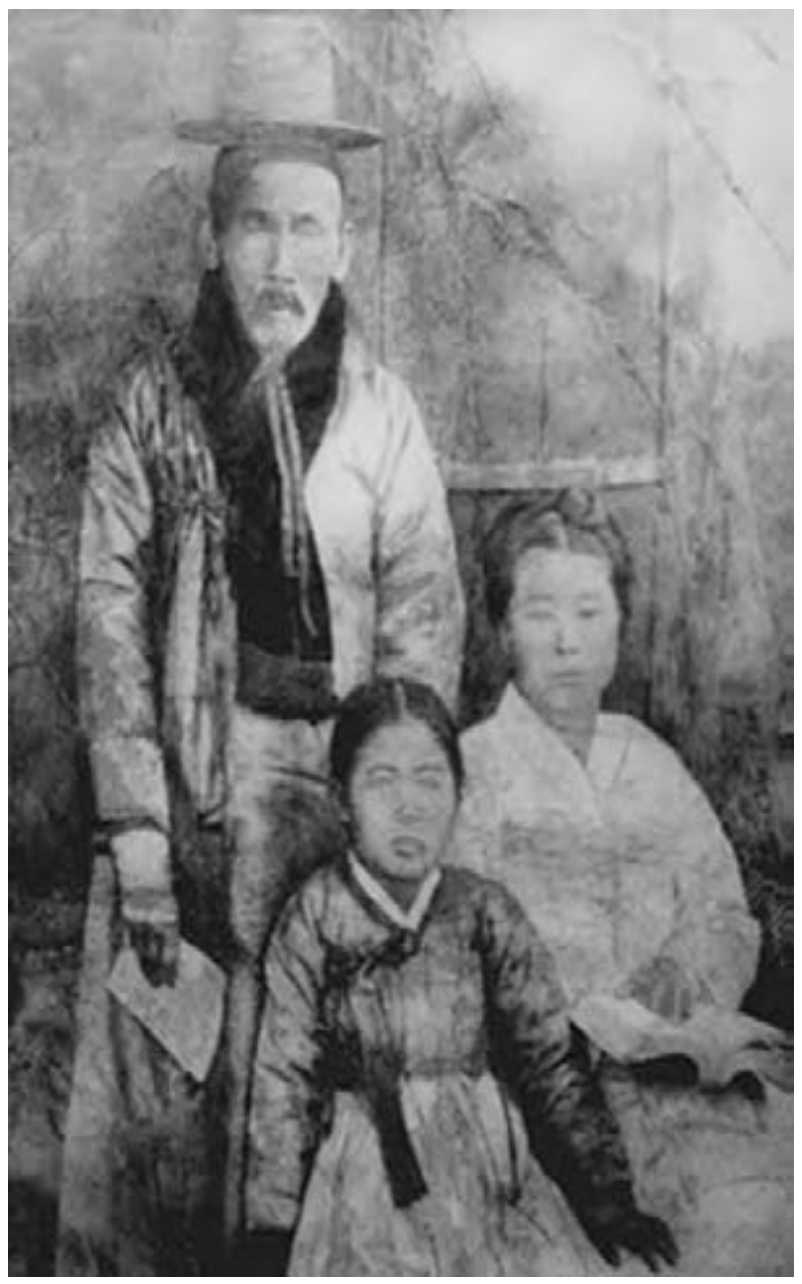

\section{Under the Black Umbrella}

VOICES FROM COLONIAL KOREA, I9IO-I945

HILDI KANG

Cornell University Press

Ithaca \& London 


\section{Copyright (C) 200I by \\ Cornell University.}

All rights reserved.

Except for brief quotations in a review, this book, or parts thereof, must not be reproduced in any form without permission in writing from the publisher. For information, address

Cornell University Press, Sage House, 512 East State Street, Ithaca, New York 14850 .

First published 200I by Cornell University Press First printing, Cornell Paperbacks, 2005

Printed in the United States of America

\section{Library of Congress Cataloging-in-Publication Data}

Kang, Hildegarde S., I934-

Under the black umbrella : voices from colonial

Korea, I910-I945 / Hildi Kang.

p. cm.

Includes bibliographical references and index.

ISBN-I3: 978-0-80I4-3854-7 (cloth : alk. paper)

ISBN-I3: 978-0-80I4-7270-I (pbk. : alk. paper)

I. Korea-History-Japanese occupation, I9IO-I945.

2. Korea-Social conditions-2oth century.

3. Japan-Politics and government-I912-I945.

I. Title.

DS9I6.54.H33 20OI

$$
\text { 95I.9'03-dc2I } \quad 00-011299
$$

Cornell University Press strives to use environmentally responsible suppliers and materials to the fullest extent possible in the publishing of its books.

Such materials include vegetable-based, low-VOC inks and acid-free papers that are recycled, totally chlorine-free, or partly composed of nonwood fibers. For further information, visit our website at www.cornellpress.cornell.edu.

I 3579 Cloth printing IO 8642

579 Paperback printing 10 864 
For

my Honorable Father-in-law

Kang Byung Ju

who made me aware of the voices

and

the Korean elders

who shared their life stories

with apologies

to the many

whose equally powerful stories

we were not able to include. 

The reason for writing is to shelter something from death.

ANDRE GIDE 
